\title{
OPINIE NA TEMAT SZCZEPIENIA PRZECIWKO GRYPIE WŚRÓD PRACOWNIKÓW OCHRONY ZDROWIA - DONIESIENIE WSTĘPNE
}

\section{OPINIONS ON VACCINATION AGAINST INFLUENZA AMONG HEALTH CARE PROFESSIONALS - PRELIMINARY REPORT}

\author{
Anna Marlena Grzela', Mariusz Panczyk², Joanna Gotlib² \\ studentka pielęgniarstwa \\ Warszawski Uniwersytet Medyczny \\ ${ }^{2}$ Zakład Dydaktyki i Efektów Kształcenia \\ Warszawski Uniwersytet Medyczny
}

DOI: http://dx.doi.org/10.20883/pielpol.2016.4

\section{STRESZCZENIE}

Wstęp. Centrum Prewencji i Kontroli Zakażeń w USA (CDC) oraz określony przez Głównego Inspektora Sanitarnego polski Program szczepień ochronnych (PSO) zalecają pracownikom medycznym regularne szczepienia przeciwko grypie. Ich celem jest zapewnienie zarówno bezpieczeństwa pacjentom, jak i prawidłowego funkcjonowania placówek medycznych.

Cel. Celem pracy była ocena wiedzy i postaw oraz częstości szczepień przeciwko grypie wśród wybranych grup pracowników służby zdrowia.

Materiał i metody. W badaniu wzięła udział grupa 90 pracowników ochrony zdrowia, w tym 30 farmaceutów, 30 lekarzy i 30 pielęgniarek. Badani mieszkali w Warszawie i jej najbliższej okolicy. Respondenci dobrowolnie wypełniali anonimową autorską ankietę.

Wyniki. W badanej grupie 3\% farmaceutów, 17\% pielęgniarek i $43 \%$ lekarzy deklaruje regularne szczepienia przeciwko grypie. W obecnej sytuacji epidemiologicznej szczepienia przeciwko grypie są szczególnie istotne według 13\% farmaceutów i pielęgniarek oraz $50 \%$ lekarzy. Zdecydowana większość personelu nie ma pewności co do bezpieczeństwa szczepień, tylko 30\% farmaceutów, $40 \%$ pielęgniarek i $70 \%$ lekarzy uznaje, że są bezpieczne.

Wnioski.

1. Mały procent personelu medycznego regularnie szczepi się przeciwko grypie, szczególnie niski stopień zaszczepienia występuje w grupie farmaceutów.

2. Wśród personelu lekarskiego obserwuje się wyższą niż wśród pielęgniarek i farmaceutów świadomość dotyczącą potrzeby szczepień.

3. Wyniki badań wskazują na rosnącą potrzebę szkoleń na temat bezpieczeństwa i skuteczności szczepień przeciwko grypie, ponieważ duża część personelu medycznego nisko ocenia wiarygodność tej formy profilaktyki zakażeń.

SŁOWA KLUCZOWE: grypa, szczepienia, lekarze, pielęgniarki, farmaceuci, postawy, opinie, ochrona zdrowia.

\section{ABSTRACT}

Introduction. Regular vaccinations against influenza are recommended to all health professionals by the American Centers for Disease Control and Prevention (CDC) and the polish Plan for preventive vaccination (PSO) as defined by the Chief Sanitary Inspector. This is supposed to ensure safety for patients and proper functioning of the health care centres.

Aim. Assessment of knowledge and attitudes as well as the rate of vaccination against influenza among selected groups of health professionals.

Material and methods. The study enrolled a total of 90 health care professionals, including 30 pharmacists, 30 physicians, and 30 nurses from Warsaw and its neighbourhood. Respondents voluntarily filled in an anonymous questionnaire developed by the authors.

Results. Among the study group, $3 \%$ of the pharmacists, $17 \%$ of the nurses, and $43 \%$ of the physicians reported to be vaccinated against influenza regularly. With the present epidemiological situation, vaccinations against influenza were of particular importance for $13 \%$ of the pharmacists and nurses as well as $50 \%$ of the physicians. A vast majority of the medical personnel had no certainty about the safety of vaccination, only $30 \%$ of the pharmacists, $40 \%$ of the nurses, and $70 \%$ of the physicians considered them safe.

Conclusions.

1. A small percentage of medical personnel regularly get vaccinations against influenza, with a particularly low vaccination rate among pharmacists.

2. Better awareness of the necessity for vaccination was observed among physicians compared to the groups of nurses and pharmacists.

3. Study results demonstrated a growing need for trainings on safety and effectiveness of vaccination against influenza since the reliability of this form of infection prevention was rated low by a great number of health care professionals.

KEYWORDS: influenza, vaccination, physicians, nurses, pharmacists, attitudes, opinions, health protection. 


\section{Wstęp}

Grypa to choroba zakaźna wywoływana przez trzy typy wirusów - A, B i C. Niebezpieczne dla zdrowia pacjentów są przede wszystkim powikłania pogrypowe. Są one szczególnie groźne dla osób z grup podwyższonego ryzyka [1]. W kolejnych sezonach jesienno-zimowych grypa powraca $z$ różnym nasileniem i obserwujemy coroczne epidemie. Według danych z 2007 r. na grypę rocznie zapada około 5-25\% populacji, mimo to choroba jest stale lekceważona. Najskuteczniejszą i najlepszą metodą ochrony przed grypą są sezonowe szczepienia profilaktyczne.

Wirus grypy charakteryzuje się dużą zmiennością genetyczną, co prowadzi do powstawania nowych szczepów. $Z$ tego powodu nie można przeprowadzić jego skutecznej eradykacji. Dlatego też infekcje wywołane wirusem grypy mogą się powtarzać wiele razy [2]. Co roku jest produkowana według wytycznych WHO nowa szczepionka przeciwko grypie [3]. Regularne szczepienia pracowników medycznych są ważne dla bezpieczeństwa pacjentów i prawidłowego funkcjonowania placówek medycznych. Dlatego od 2007 r. Centrum Prewencji i Kontroli Zakażeń w USA (CDC) i Główny Inspektor Sanitarny w polskim Programie szczepień ochronnych zalecają personelowi medycznemu szczepienia przeciwko grypie [1].

\section{Cele pracy}

Celem pracy była ocena wiedzy i postaw oraz częstości szczepień przeciwko grypie wśród wybranych grup pracowników służby zdrowia.

\section{Materiał i metody}

\section{Charakterystyka badanej grupy}

W badaniu wzięła udział grupa 90 pracowników ochrony zdrowia: 30 farmaceutów z aptek z Warszawy i jej okolic w promieniu $80 \mathrm{~km}$ oraz 30 lekarzy i 30 pielęgniarek z następujących szpitali: Wojewódzki Szpital Bródnowski, Wojskowy Instytut Medyczny, Instytut Kardiologii, Mazowieckie Centrum Chorób Płuc i Gruźlicy w Otwocku, oraz przychodni z Warszawy i jej okolic w promieniu $80 \mathrm{~km}$.

Badanie miało charakter dobrowolny, ale zdecydowana większość lekarzy oraz wszystkie pielęgniarki i farmaceuci zaproszeni do badania wzięli w nim udział. Wśród uczestników rozprowadzono 105 ankiet, z których 90 zostało wypełnionych (85,71\% zwrotu). Wszystkie zwrócone ankiety zostały włączone do badania.

Badana grupa respondentów charakteryzowała się brakiem rozkładu normalnego, jeśli chodzi o wiek (test Shapiro-Wilka, $p=0,0045$ ) (Tabela 1).
Tabela 1. Parametry opisu statystycznego badanej populacji - wiek Table 1. Statistical parameters of the study population: age

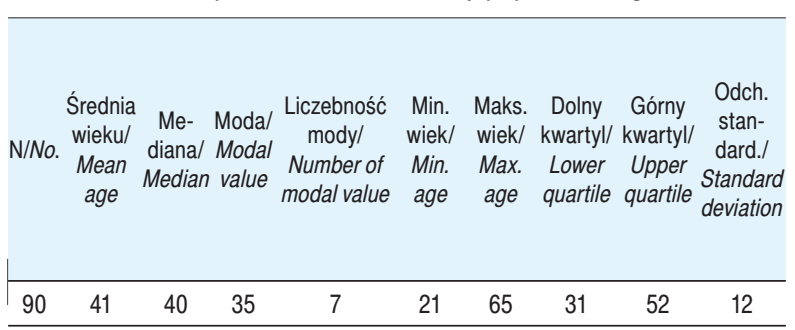

Źródło: opracowanie własne

Source: author's own analysis

Porównanie wieku respondentów reprezentujących różne zawody wskazuje na istotne różnice między farmaceutami a pielęgniarkami (test $U$ Manna-Whitneya, $p=0,0002$ ) i lekarzami (test U Manna-Whitneya, $p=0,0108$ ). Natomiast pielęgniarki i lekarze biorący udział w badaniu nie różnili się istotnie wiekiem (test U Manna-Whitneya, $p=0$,2905) (Tabela 2).

Tabela 2. Parametry opisu statystycznego badanej populacji - wiek w grupach zawodowych

Table 2. Statistical parameters of the study population: age in groups of professionals

\begin{tabular}{|c|c|c|c|c|c|}
\hline & N/No. & $\begin{array}{l}\text { Średnia } \\
\text { wieku/ } \\
\text { Mean } \\
\text { age }\end{array}$ & $\begin{array}{l}\text { Minimalny } \\
\text { wiek/ } \\
\text { Minimum } \\
\text { age }\end{array}$ & $\begin{array}{l}\text { Maksymalny } \\
\text { wiek/ } \\
\text { Maximum } \\
\text { age }\end{array}$ & $\begin{array}{l}\text { Odchyle- } \\
\text { nie stan- } \\
\text { dardowe/ } \\
\text { Standard } \\
\text { deviation }\end{array}$ \\
\hline $\begin{array}{l}\text { Farma- } \\
\text { ceuci/ } \\
\text { Pharma- } \\
\text { cists }\end{array}$ & 30 & 35,1 & 21,0 & 65,0 & 11,49 \\
\hline $\begin{array}{l}\text { Pielę- } \\
\text { gniarki/ } \\
\text { Nurses }\end{array}$ & 30 & 45.4 & 23,0 & 59,0 & 9,35 \\
\hline $\begin{array}{c}\text { Lekarze/ } \\
\text { Physi- } \\
\text { cians }\end{array}$ & 30 & 42,4 & 27,0 & 62,0 & 11,73 \\
\hline
\end{tabular}

Źródło: opracowanie własne

Source: author's own analysis

Kobiety stanowiły zdecydowaną większość respondentów (79\% vs $21 \%$ mężczyzn). Ponadto porównanie wieku respondentów względem płci nie wskazuje na istotne różnice między tymi grupami (test U Manna-Whitneya, $p=0,9921$ ) (Tabela 3).

Porównanie liczby lat stażu zawodowego respondentów w badanych grupach zawodowych wskazuje, że farmaceuci i lekarze nie różnili się pod tym względem (test $U$ Manna-Whitneya, $p=0,0823$ ). Natomiast zarówno lekarze, jak i farmaceuci charakteryzowali się istotnie krótszym stażem niż grupa badanych pielęgniarek (test $U$ Manna-Whitneya, odpowiednio $p=0,0237$ i $p=0,00002)$ (Tabela 4). 
Tabela 3. Parametry opisu statystycznego badanej populacji - wiek według płci

Table 3. Statistical parameters of the study population: age by gender

\begin{tabular}{|c|c|c|c|c|c|}
\hline & N/No. & $\begin{array}{c}\text { Średnia } \\
\text { wieku/ } \\
\text { Mean age }\end{array}$ & $\begin{array}{l}\text { Minimalny } \\
\quad \text { wiek/ } \\
\text { Minimum age }\end{array}$ & $\begin{array}{l}\text { Maksymalny } \\
\text { wiek/ } \\
\text { Maximum } \\
\text { age }\end{array}$ & $\begin{array}{c}\text { Odchylenie } \\
\text { standardowe/ } \\
\text { Standard } \\
\text { deviation } \\
\end{array}$ \\
\hline $\begin{array}{l}\text { Kobiety/ } \\
\text { Women }\end{array}$ & 71 & 40,9 & 21,0 & 62,0 & 10,79 \\
\hline $\begin{array}{l}\text { Mężczyź- } \\
\text { ni/Men }\end{array}$ & 19 & 41,4 & 21,0 & 65,0 & 14,70 \\
\hline
\end{tabular}

Źródło: opracowanie własne

Source: author's own analysis

Tabela 4. Parametry opisu statystycznego badanej populacji - długość stażu pracy w zawodzie

Table 4. Statistical parameters of the study population: the length of service in the profession

\begin{tabular}{|c|c|c|c|c|c|c|c|c|}
\hline & N/ & $\begin{array}{l}\text { Średnia } \\
\text { stażu/ } \\
\text { Mean } \\
\text { length } \\
\text { of } \\
\text { service }\end{array}$ & $\begin{array}{l}\text { Min. stażu/ } \\
\text { Min. } \\
\text { length } \\
\text { of } \\
\text { service }\end{array}$ & $\begin{array}{l}\text { Maks. } \\
\text { stażul } \\
\text { Max. } \\
\text { length } \\
\text { of } \\
\text { service }\end{array}$ & $\begin{array}{c}\text { Odchylenie } \\
\text { standard./ } \\
\text { Standard } \\
\text { deviation }\end{array}$ & $\begin{array}{l}\text { Mediana/ } \\
\text { Median }\end{array}$ & $\begin{array}{c}\text { Dolny } \\
\text { kwartyl/ } \\
\text { Lower } \\
\text { quartile }\end{array}$ & $\begin{array}{c}\text { Górny } \\
\text { kwartyl/ } \\
\text { Upper } \\
\text { quartile }\end{array}$ \\
\hline $\begin{array}{l}\text { Farmaceuci/ } \\
\text { Pharmacists }\end{array}$ & 30 & 10,2 & 1 & 40 & 10,26 & & & \\
\hline $\begin{array}{l}\text { Pielegnniarki/ } \\
\text { Nurses }\end{array}$ & 30 & 22,7 & 1 & 38 & 10,16 & & 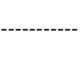 & \\
\hline $\begin{array}{l}\text { Lekarze/ } \\
\text { Physicians }\end{array}$ & 30 & 15,9 & 0 & 38 & 12,44 & & & \\
\hline $\begin{array}{c}\text { Razem/ } \\
\text { Total }\end{array}$ & 90 & 16,3 & 0 & 40 & 12,02 & 15 & 5,00 & 28,00 \\
\hline
\end{tabular}

Źródło: opracowanie własne

Source: author's own analysis

Analiza grupy lekarzy i pielęgniarek wskazuje na istotnie statystyczne różnice między ich wiekiem a miejscem pracy (test U Manna-Whitneya, $p=0,0154$ ). Pracownicy przychodni to zdecydowanie starsze osoby w porównaniu z pracownikami szpitali w badanej grupie (Tabela 5).

Tabela 5. Parametry opisu statystycznego badanej grupy lekarzy i pielęgniarek - wiek a miejsce pracy

Table 5. Statistical parameters of study groups of physicians and nurses: age and workplace

\begin{tabular}{|c|c|c|c|c|c|c|c|c|}
\hline & $\begin{array}{l}\text { N/ } \\
\text { No. }\end{array}$ & $\begin{array}{l}\text { Średnia } \\
\text { wieku/ I } \\
\text { Mean } \\
\text { age }\end{array}$ & $\begin{array}{c}\text { Mediana/ } \\
\text { Median }\end{array}$ & $\begin{array}{l}\text { Min. } \\
\text { wiek/ } \\
\text { Min. } \\
\text { age }\end{array}$ & $\begin{array}{c}\text { Maks. } \\
\text { wiek/ } \\
\text { Max. } \\
\text { age }\end{array}$ & $\begin{array}{c}\text { Dolny } \\
\text { kwartyl/ } \\
\text { Lower } \\
\text { quartile }\end{array}$ & $\begin{array}{l}\text { Górny } \\
\text { kwaryl/ } \\
\text { Upper } \\
\text { quartile }\end{array}$ & $\begin{array}{l}\text { Odchyl. } \\
\text { standard./ } \\
\text { Standard } \\
\text { deviation }\end{array}$ \\
\hline $\begin{array}{c}\text { Przychodnie/ } \\
\text { Outpatient } \\
\text { clinics }\end{array}$ & 25 & 47,12 & 48,00 & 28,00 & 60,00 & 40,00 & 55,00 & 9,07 \\
\hline $\begin{array}{l}\text { Szpitale/ } \\
\text { Hospitals }\end{array}$ & 31 & 40,38 & 38,00 & 23,00 & 62,00 & 30,00 & 50,00 & 10.96 \\
\hline
\end{tabular}

Źródło: opracowanie własne

Source: author's own analysis

\section{Metody i narzędzia badawcze}

Narzędziem badawczym był autorski kwestionariusz ankiety. Udział w badaniu był dobrowolny i anonimowy. Uczestnicy wypełniali specjalnie przygotowaną dla potrzeb badania autorską ankietę zawierającą 17 pytań zamkniętych (w tym 3 półotwarte z możliwością wyrażenia własnej opinii). Pytania dotyczyły:

- ostatnich szczepień przeciwko grypie (pytania 1 i 16);

- $\quad$ przyczyn nieszczepienia się (pytanie 2);

- opinii o występowaniu działań niepożądanych po szczepieniu (pytania 8 i 9);

- opinii na temat zaleceń dotyczących szczepień (pytania 3, 4, 5);

- oceny przez respondentów skuteczności i bezpieczeństwa szczepień (pytania 6 i 7);

- znajomości grup chorych najbardziej narażonych na powikłania (pytanie 10);

- $\quad$ opinii na temat refundacji szczepień (pytanie 12);

- $\quad$ oceny, czy warto szczepić się (pytanie 11) oraz czy jest to najlepsza metoda zapobiegania grypie (pytanie 13);

- znajomości poszczególnych preparatów handlowych szczepionek (pytanie 17).

Ponadto poproszono uczestników o ocenę profilaktyki grypy szczepieniami sezonowymi (pytanie 14) i w okresie ostatniej pandemii (pytanie 15).

\section{Opracowanie statystyczne}

Do analizy statystycznej wykorzystano program firmy StatSoft STATISTICA 9.0 (licencja Warszawskiego Uniwersytetu Medycznego).

Charakterystykę grupy badanej pod względem rozkładu częstości wieku przeprowadzono testem Shapiro-Wilka. Ponieważ porównywane w opisie charakterystyki podgrupy poszczególnych zawodów medycznych względem wieku nie miały rozkładu normalnego, to do analizy użyto nieparametrycznego testu U Manna-Whitneya. Natomiast analizę statystyczną różnic w tabelach wielodzielczych cech jakościowych wykonano testem chi-kwadrat Pearsona (test $\chi^{2}$ niezależności). Badanie zależności między niektórymi cechami jakościowymi a wiekiem respondentów w podgrupach zawodowych wykonano testem Kruskala-Wallisa $(p<0,05)$.

\section{Wyniki}

W badanej grupie niewielki odsetek personelu medycznego był szczepiony przeciwko grypie w ostatnich dwóch sezonach epidemiologicznych. Szczególnie rzadko szczepieni byli farmaceuci (6\%) i pielęgniarki (20\%). Natomiast 66\% lekarzy szczepiło się regularnie. Analiza częstości szczepień grup personelu medycz- 
nego wskazuje na istotne różnice statystyczne (test chi-kwadrat, $p=0,00043)$. Lekarze znacznie częściej niż pielęgniarki i farmaceuci szczepili się w obecnym oraz ubiegłym sezonie epidemiologicznym. Analiza częstości szczepień personelu medycznego względem płci nie wskazuje na zależność między płcią a częstością deklarowanego zaszczepienia (test chi-kwadrat, $p=1,0000$ ). Analiza częstości deklarowanych szczepień w zależności od miejsca pracy wykazuje istotne różnice statystyczne (test chi-kwadrat, $p=0,00531$ ). Wśród pracowników aptek dominuje grupa, która nigdy się nie szczepiła, natomiast pracownicy przychodni znacznie częściej niż inne grupy zdecydowali, by zaszczepić się w obecnym sezonie epidemiologicznym. W analizie zależności między wiekiem a deklarowanym zaszczepieniem nie wskazano na istotne statystycznie równice (test Kruskala-Wallisa, $p=0,6038$ ). Jednakże widoczna jest tendencja ukierunkowana na deklarowanie szczepienia w obecnym sezonie wśród starszego personelu medycznego (mediana wieku powyżej 42 lat). Częstość deklarowanego zaszczepienia badanych grup względem czasu trwania stażu pracy wykazuje tendencję do wzrostu w zależności od liczby lat przepracowanych w zawodzie (mediana czasu trwania stażu pracy powyżej 16 lat). Jednakże zależność ta nie była istotna statystycznie (test Kruskala-Wallisa, $p=0,5806$ ).

Większość badanych wskazuje na brak powikłań poszczepiennych. Jedynie 13\% farmaceutów, 10\% pielęgniarek i $6 \%$ lekarzy podaje, iż mieli powikłania w postaci infekcji grypopodobnej. Z kolei $6 \%$ farmaceutów i 6\% lekarzy wskazało na uogólniony odczyn poszczepienny. Zdecydowana większość farmaceutów (96\%) i pielęgniarek (86\%) nie zamierza zaszczepić się tegoroczną szczepionką postpandemiczną, natomiast 53\% lekarzy deklaruje, że się zaszczepi. Większość personelu medycznego nie wykazuje potrzeby profilaktyki grypy poprzez szczepienie w obecnym sezonie epidemiologicznym. Bardzo odmiennie w poszczególnych grupach rozkładały się przyczyny nieszczepienia się przeciwko grypie. W grupie pielęgniarek i lekarzy dominowała obawa przed szczepionką i powikłaniami poszczepiennymi. W grupie farmaceutów najczęstszą przyczyną nieszczepienia się jest brak wskazań do szczepienia (38\%), a także deklarowanie stosowania metod nieswoistych zamiast szczepienia (31\% farmaceutów i $32 \%$ pielęgniarek). Ponadto $27 \%$ farmaceutów rezygnuje ze szczepień, jako powód podając obawy przed skutkami szczepienia. Odmiennie ankietowani odpowiadali na pytanie dotyczące wskazania grup, które powinny regularnie szczepić się przeciwko grypie. Farmaceuci i pielęgniarki oceniają, że szczepienia są głównie dla osób z grup ryzyka, a 43\% lekarzy sugeruje, że każdy powinien być szczepiony. Dominującą opinią we wszystkich badanych grupach było, że osoby zdrowe, które rzadko chorują, nie powinny szczepić się przeciwko grypie, jednakże 16\% farmaceutów i 23\% pielęgniarek oraz $43 \%$ lekarzy zaleciłoby szczepienie również i w tych przypadkach. Natomiast osobom, które często chorują, zdecydowana większość badanych zalecałaby szczepienia. Jedynie 10\% lekarzy i 10\% farmaceutów nie poleca szczepienia tym osobom.

Bardzo duży procent farmaceutów i pielęgniarek nie ma zdania na temat bezpieczeństwa szczepienia (odpowiednio 63\% i 60\%), przy czym 70\% lekarzy ocenia, że szczepienia są bezpieczne. Duży odsetek personelu medycznego obawia się skutków ubocznych szczepienia: $57 \%$ pielęgniarek, $47 \%$ farmaceutów i $27 \%$ lekarzy. W grupie lekarzy $60 \%$ nie odczuwa żadnych obaw związanych ze szczepieniem.

W grupie $63 \%$ lekarzy i $40 \%$ pielęgniarek dominuje ocena, że szczepienia nie są skuteczne, natomiast $46 \%$ farmaceutów uważa, że szczepienia są skuteczne, ale nie chronią przed infekcjami grypopodobnymi. Skuteczność szczepień deklaruje 30\% lekarzy, 20\% pielęgniarek i 16\% farmaceutów. Opinie są bardzo podzielone wśród pracowników służby zdrowia.

Analiza opinii grup badanych, czy warto szczepić się na grypę, wykazała istotne różnice statystyczne (test chi-kwadrat, $p=0,01456$ ). Lekarze zdecydowanie częściej od pozostałych grup zawodowych wyrażają opinię, że szczepienia są szczególnie istotne w obecnej sytuacji epidemiologicznej. Natomiast farmaceuci w przeciwieństwie do innych grup najczęściej wskazują, że szczepienia są dodatkową formą ochrony dla osób o dużym ryzyku zachorowania. Z kolei pielęgniarki częściej niż pozostałe grupy nie miały zdania w tej kwestii, jednakże aż $46 \%$ w tej grupie stwierdza, że szczepienia są najważniejsze w grupach najwyższego ryzyka zachorowania.

Nie wykazano istotnej zależności między opinią na temat korzyści związanych ze szczepieniem a wiekiem respondentów (test Kruskala-Wallisa, $p=0$,0693). Można jednak wskazać na tendencję w opiniach starszych pracowników (mediana wieku powyżej 40 lat) mówiącą o istotności szczepień w obecnej sytuacji epidemiologicznej, przy równocześnie sporym odsetku osób z tej samej grupy wiekowej (mediana wieku powyżej 50 lat) niemającej zdania na ten temat.

Podobną tendencję, ale istotną statystycznie, zaobserwowano w analizie zależności między liczbą lat stażu a opinią w kwestii korzyści płynących ze szczepień (test Kruskala-Wallisa, $p=0,0329$ ). Grupa osób z medianą stażu pracy powyżej 15 lat wskazuje na istotność szczepień w obecnej sytuacji epidemiologicznej, przy równocześnie sporym odsetku braku zdania na ten temat wśród pracowników z medianą stażu powyżej 25 lat. 
Opinia personelu medycznego o refundacji szczepień kształtowała się następująco: 30\% pielęgniarek, $23 \%$ lekarzy i 23\% farmaceutów uważa, że powinno się zrefundować szczepienia każdemu, a odpowiednio 60\%, 53\%, 43\% twierdzi, że wyłącznie osobom z grup ryzyka.

Według 63\% lekarzy, 30\% pielęgniarek i 23\% farmaceutów szczepienia są najlepszą metodą profilaktyki. Ale 33\% farmaceutów uważa, że szczepienia nie są najlepsze w zapobieganiu grypie i kolejne 33\% w tej grupie stwierdza, że metody nieswoiste są porównywalnie skuteczne.

Bardzo różne wśród grup badanych były oceny immunoprofilaktyki grypy w Polsce. Dominującą opinią we wszystkich grupach zawodowych (53\% lekarzy, 47\% pielęgniarek i 33\% farmaceutów) było stwierdzenie, że w profilaktyce robimy, co możemy, ale każdy pacjent sam decyduje, czy podda się szczepieniu. Natomiast w pytaniu o ocenę szczepień w trakcie pandemii wirusem A/H1N1 dominowała ocena negatywna. Na ukształtowanie takiej oceny wpłynął fakt, że wyprodukowano szczepionki wątpliwej skuteczności.

Najlepszą znajomością preparatów handlowych szczepionek wykazali się farmaceuci. $Z$ analizy różnic w znajomości szczepionki Fluarix ${ }^{\circledR}$ w poszczególnych grupach zawodowych wynika, że farmaceuci znacznie częściej niż pozostałe grupy wykazywali się znajomością tego preparatu (test chi-kwadrat, $p=0,0356$ ). Ponadto farmaceuci i lekarze znacznie częściej niż pielęgniarki wskazują na preparat Influvac ${ }^{\circledR}$ (test chi-kwadrat, $p=0,0004)$. Nie wykazano istotnych różnic statystycznych w przypadku znajomości preparatów Idflu ${ }^{\circledR}$ oraz Vaxigrip $^{\circledR}$ (test chi-kwadrat, odpowiednio $p=0,3663$ i $p=0,9432)$. Ponadto preparat Vaxigrip ${ }^{\circledR}$ jest najlepiej rozpoznawanym produktem spośród wszystkich wskazanych w ankiecie.

Wyniki badania znajomości grup ryzyka najbardziej narażonych na powikłania pogrypowowe wskazują, że mniej więcej jedna trzecia respondentów, niezależnie od grupy zawodowej, potrafi prawidłowo określić kolejność poszczególnych grup pacjentów, od najbardziej narażonych do najmniej. Najczęściej wymieniana przez respondentów grupa chorych uznawana za najbardziej narażoną na powikłania pogrypowe to osoby w wieku starszym (wskazane przez 72\% respondentów), natomiast za najmniej narażoną grupę uznawano osoby w wieku 20-40 lat (wskazane przez 85\% respondentów).

\section{Dyskusja}

Według doniesień amerykańskich pracownicy służby zdrowia należą do grupy osób, które powinny być regularnie szczepione przeciwko grypie [9]. Wyniki badania wskazują jednak, że poziom zaszczepienia naszego personelu medycznego w obecnym sezonie epidemio- logicznym wynosi ponad $21 \%$. Podobnie nieco ponad 25\% badanych stwierdziło, że szczepienia są szczególnie istotne wobec aktualnej sytuacji epidemiologicznej. Poziom zaszczepienia polskiej służby zdrowia jest niski.

Bardzo niski, około 3-procentowy, poziom zaszczepienia farmaceutów w tym roku jest niepokojący. Świadomość potrzeby regularnych szczepień w tej grupie wynosi ponad 13\%. Farmaceuci obok lekarzy stanowią źródło wiarygodnej konsultacji dla pacjentów, którzy przychodząc do aptek, są już często w stanie infekcji. Kontakt farmaceutów z pacjentami ma innych charakter niż pielęgniarek oraz lekarzy w warunkach szpitalnych czy w przychodni. Z drugiej strony pracownicy aptek, jako osoby upoważnione do udzielania porady i wydawania preparatów szczepionek, również powinni zadbać o własną odporność po szczepieniu, dla korzyści własnych oraz pacjentów.

Personel pielęgniarski ma zdecydowanie najczęstszy bezpośredni kontakt z ludźmi chorymi. Poziom ostatnich szczepień w tej grupie to niecałe 17\%. Główny zaobserwowany problem w grupie badanych pielęgniarek to brak wiedzy na temat potrzeby profilaktyki grypy, który deklaruje niecałe 27\%. Tylko 13\% pielęgniarek jest przekonanych o potrzebie regularnych szczepień. Konieczna jest edukacja personelu pielęgniarskiego i zwiększenie stopnia zaszczepienia szczególnie na oddziałach szpitalnych, gdzie stopień deklarowanych szczepień był nawet niższy niż w przychodniach.

Z badań wynika, że lekarze szczepią się znacznie częściej (43\%) od pielęgniarek i farmaceutów. Obserwowana znacząca różnica w stopniu zaszczepienia lekarzy i pielęgniarek pracujących na tych samych oddziałach wskazuje być może na konieczność wspólnych szkoleń dla zespołów pielęgniarsko-lekarskich.

Problem zaszczepienia pielęgniarek oraz braku edukacji został opisany w badaniu szczepień przeciwko grypie, przeprowadzonym przez Katedrę i Zakład Medycyny Rodzinnej Warszawskiego Uniwersytetu Medycznego. Badaniem objęto personel medyczny i studentów. Okazało się, że nie są oni dostatecznie świadomi potrzeby szczepień przeciwgrypowych. Wyniki i wnioski z niniejszych badań wskazują na małą liczbę zaszczepionego personelu i studentów, przy równocześnie dużej gotowości studentów do bezpłatnego zaszczepienia [11]. Z powyższych obserwacji wynika, że w ciągu ostatnich 2 lat niewiele udało się zmienić w kwestii profilaktyki grypy poprzez szczepienia personelu medycznego. Sytuację komplikuje dodatkowo trudna sytuacja finansowa polskich szpitali, a także fakt, że Narodowy Fundusz Zdrowia nie finansuje szczepień personelu medycznego.

Z badań wynika, że zdecydowana większość personelu zaszczepionego w obecnym oraz ubiegłym sezonie 
to osoby powyżej 42 lat. W celu zwiększenia poziomu zaszczepienia wśród pracowników medycznych należałoby skierować działania edukacyjne głównie w stronę młodszego personelu. Warto byłoby zwrócić uwagę starszemu personelowi na rolę edukacyjną wobec młodszych kolegów, którą umożliwia wspólna praca w szpitalach i przychodniach. Młodzi pracownicy medyczni powinni brać przykład ze swoich starszych kolegów, kierowników i przełożonych, którzy podejmują działania w celu profilaktyki grypy.

Oprócz wspomnianych powyżej problemów związanych z finansowaniem w Polsce profilaktyki również inne negatywne zjawiska mogły przyczynić się do spadku zaufania do szczepień. Przywołując wypowiedź Fiony Godlee, redaktor naczelnej „British Medical Journal”, istotne w trakcie trwania ostatniej pandemii grypy było zjawisko konfliktu interesów wśród doradców Światowej Organizacji Zdrowia, którzy łączyli funkcję doradczą z funkcją przedstawiciela handlowego firm farmaceutycznych produkujących leki antywirusowe i szczepionki [12]. Wiarygodność preparatów szczepionkowych oraz koncernów farmaceutycznych została podważona, co mogło przyczynić się do zmniejszenia obserwowanego poziomu szczepień.

Z przeprowadzonych badań wynika, że najbardziej znane pracownikom medycznym preparaty handlowe szczepionek to Vaxigrip (99\%) i Influvac (79\%). Mniej znany jest Fluarix (47\%), Idflu (18\%) i Agrippal (8\%).

W 2007 r. Krajowy Ośrodek ds. Grypy oszacował, że roczna sprzedaż szczepionek przeciwko grypie, w zależności od roku, utrzymywała się na poziomie ok. 2,5-3 mln dawek, co nie przekracza zapotrzebowania $10 \%$ społeczeństwa. Dla porównania w Europie Zachodniej stopień zaszczepienia utrzymuje się na poziomie ok. 25\% w stosunku do populacji [13]. Niski procent szczepiących się Polaków świadczy o niewystarczającym poziomie świadomości społecznej dotyczącej korzyści wynikających ze szczepień. Warto byłoby przeprowadzać kampanie na temat kosztów prewencji, leczenia grypy oraz skutków wynikających z choroby i jej powikłań.

Badania personelu zajmującego się opieką nad dziećmi w domach dziecka również wskazują na niski poziom zaszczepień (19,5\% badanych). Autorzy tych badań we wnioskach stwierdzili, że osoby zajmujące się małymi dziećmi należy lepiej edukować w zakresie profilaktyki przeciwgrypowej [14]. Z powodu grypy oraz podejrzeń grypy w 2008 r. najczęściej do szpitala kierowano najmłodsze dzieci oraz osoby powyżej 65. roku życia. Szpitale pediatryczne co roku z powodu objawów ze strony układu oddechowego przyjmują dużą liczbę chorych (98\% skierowań w danym okresie). Natomiast w grupie osób powyżej 65 lat objawy ze strony układu oddechowego stanowią 96\% skierowań do hospitalizacji. Najczęstszym powikłaniem grypy u najmłodszych jest zapalenie oskrzelików, a u starszych - zapalenie płuc [15].

Dla porównania według opinii badanego personelu medycznego grupy najbardziej narażone na powikłania pogrypowe to osoby starsze (72\%) i dzieci (20\%). Za grupę najmniej narażoną na powikłania pogrypowe 85\% badanych uznało chorych w wieku 20-40 lat. W 2009 r. zostało przeprowadzone badanie pacjentów hospitalizowanych w Szpitalu Zakaźnym w Warszawie z powodu grypy wywołanej wariantem wirusa A/H1N1. Zdecydowana większość chorych była wówczas w wieku 20-29 lat, w tym było prawie dwa razy więcej kobiet. Aż u 38\% jako powikłanie choroby potwierdzono zapalenie płuc. Przebieg choroby był najczęściej lekki i średni [16]. Podobnie jak w poprzednim sezonie epidemiologicznym i w tym roku osoby młode są narażone na zachorowanie na grypę, ponieważ wirus A/H1N1 nadal jest obecny i aktywny. W wyniku badań laboratoryjnych w sezonie 2006/2007 potwierdzono 60\% zachorowań na grypę wywołanych przez wirusy typu A, a 40\% - przez wirusy typu B [15].

W niektórych zachodnich krajach są przeprowadzane analizy ekonomiczne kosztów związanych z grypą. W USA w zależności od sezonu epidemicznego koszty wahają się od 76 do 167 mld dolarów [17]. W Polsce nie są monitorowane koszty leczenia i hospitalizacji z powodu grypy. Koszt szczepienia to ok. 30-40 zł, co nie jest wysoką kwotą, choć na pewno odgrywa pewną rolę w przypadku osób starszych. Późniejsze koszty leczenia powikłań pogrypowych, takich jak zapalenie płuc, zakażenia bakteryjne i meningokokowe czy zaostrzenie istniejących chorób przewlekłych, są znacznie większe. Zalecanie szczepień przeciwko grypie, zwłaszcza osobom z grup ryzyka, należy uważać za etyczną powinność personelu medycznego [17].

Według sondażu przeprowadzonego wśród osób powyżej 60. roku życia ze szczepień na grypę skorzystało $28 \%$ badanych. Czynniki wpływające na rezygnację ze szczepień to wątpliwość w skuteczność szczepionki, obawa, że może ona spowodować chorobę, oraz duży koszt jej nabycia [18]. Grypa jest niebezpieczna dla osób starszych, szczególnie obciążonych dodatkowymi chorobami przewlekłymi. Konieczne jest uświadamianie osobom powyżej 60. roku życia, że szczepionka nie jest żadnym zagrożeniem. W przeciwieństwie do młodych ludzi osoby starsze mają już dobrą pamięć immunologiczną w wyniku przeżycia wielu epidemii, a także pandemii grypy. Dlatego szczepienia są bezpieczną i najtańszą formą profilaktyki.

Wyniki badań wskazują, że sytuacja dotycząca szczepień przeciwko grypie wśród polskiej służby zdrowia jest zła. Profilaktyka grypy powinna zajmo- 
wać ważne miejsce w pracy lekarzy, pielęgniarek i farmaceutów. Dzięki większej presji na środowisko medyczne, w postaci dokumentacji szczepień i uzasadnienia powodów odmowy zaszczepienia, poziom profilaktyki zacząłby wzrastać. Należy rozwiązać także problem braku wiedzy na temat potrzeby profilaktyki grypy, szczególnie wśród pielęgniarek i farmaceutów. Niedostateczna edukacja i brak szczepień przekładają się na niedostrzeganie problemu w praktyce w szpitalach i przychodniach. Organizacja szczepień w miejscu pracy i odpowiednia edukacja mogłyby doprowadzić do zwiększenia poziomu zaszczepienia personelu medycznego.

\section{Wnioski}

1. Mały procent personelu medycznego regularnie szczepi się przeciwko grypie, szczególnie niski stopień zaszczepienia występuje w grupie farmaceutów.

2. Wśród personelu lekarskiego obserwuje się wyższą niż wśród pielęgniarek i farmaceutów świadomość dotyczącą potrzeby szczepień.

3. Wyniki badań wskazują na rosnącą potrzebę szkoleń na temat bezpieczeństwa i skuteczności szczepień przeciwko grypie, ponieważ duża część personelu medycznego nisko ocenia wiarygodność tej formy profilaktyki zakażeń.

\section{Piśmiennictwo}

1. Życińska K, Brydak LB. Grypa i jej profilaktyka - ciągle aktualny problem medyczny. Pol Arch Med Wew. 2007; 117 (10): 464-469.

2. Brydak LB. Grypa i jej profilaktyka. Poznań: Termedia; 2004.

3. Ślusarczyk J. Grypa - choroby i możliwości profilaktyki. Gab Pryw. 2008; 9: 39-45.

4. (Dostępne w Internecie:) http://www.influenza.pl/wirus-grypy_ (data dostępu: 19.04.2011).

5. (Dostępne w Internecie:) http://www.mz.gov.pl/wwwmz/index?mr $=\mathrm{m} 10 \& \mathrm{~ms}=685 \& \mathrm{ml}=\mathrm{pl} \& \mathrm{mi}=685 \& \mathrm{mx}=0 \& \mathrm{ma}=13287$ (data dostępu: 19.04.2011).

6. Mrukowicz J. Cała prawda o grypie 2009/2010 i pandemii. Med Prakt. 2009; 12: 128-145.

7. Talarek E, Duszczyk E. Profilaktyka grypy sezonowej. Zakażenia. 2010; 10: 54-58.
8. (Dostępne w Internecie:) http://www.pis.gov.pl/userfiles/ file/Departament\%20Przeciwepidemiczny/ szczepienia/ PSO\%20na\%202011.pdf (data dostępu: 19.04.2011).

9. (Dostępne w Internecie:) http://www.cdc.gov/mmwr/preview/mmwrhtml/rr5908a1.htm?s_cid=rr5908 a1_w (data dostępu: 19.04.2011).

10. Ślusarczyk J. Aktualne problemy immunoprofilaktyki grypy. Zakażenia. 2009; 9: 57-61.

11. Zielonka T, Lesiński J, Życińska K. Szczepienia przeciwko grypie personelu medycznego warszawskich szpitali klinicznych i studentów Warszawskiego Uniwersytetu Medycznego. Med Pr. 2009; 60: 369-376.

12. (Dostępne w Internecie:) http://www.biomedical.pl/aktualnosci/grypa-ah1n1-rzut-oka-na-szczepienia-w-zeszlymroku-oraz-na-szczepienia-w-tym-sezonie-1404.html (data dostępu: 19.04.2011).

13. (Dostępne w Internecie:) http://wiadomości.onet.pl/raporty/interes-naszczepionkach, 1,3344693, wiadomosc.html (data dostępu: 19.04.2011).

14. Nitsch-Osuch A, Serwatka B, Topczewska-Cabanek A. Postrzeganie i wykonawstwo szczepień przeciw grypie wśród personelu wybranego domu dziecka w Warszawie. Fam Med Prim Care Rev. 2009; 11: 440-443.

15. Romanowska M, Czarkowski M, Nowak I. Grypa w Polsce w 2008 roku. Prz Epidemiol. 2010; 64: 175-179.

16. Cholewińska G, Higersberger J, Podlasin R. Objawy kliniczne, rozpoznanie i leczenie grypy wywołanej wirusem A/H1N1 u osób hospitalizowanych w Szpitalu Zakaźnym w Warszawie w 2009 r. Przew Epidemiol. 2010; 64: 15-19.

17. Brydak LB. Profilaktyka i diagnostyka grypy w praktyce lekarza rodzinnego. Fam Med Prim Care Rev. 2006; 8: 833-840.

18. Łukomska A. Determinanty szczepień przeciwgrypowych wśród osób w starszym wieku. Gerontol Pol. 2009; 17 (3): 114-119.

Artykuł przyjęty do redakcji: 14.11 .2015

Artykuł przyjęty do publikacji: 15.09.2015

Źródło finansowania: Praca nie jest finansowana z żadnego źródła. Konflikt interesów: Autorzy deklarują brak konfliktu interesów.

\author{
Adres do korespondencji: \\ Joanna Gotlib \\ ul. Żwirki i Wigury 61 \\ 02-091 Warszawa \\ tel.: 225720 490, fax: 225720 491, tel. kom.: +48 608108028 \\ e-mail: joanna.gotlib@wum.edu.pl \\ Zakład Dydaktyki i Efektów Kształcenia \\ Warszawski Uniwersytet Medyczny
}

